\title{
Efficacy of sildenafil therapy for pulmonary hypertension in dogs: a systematic review
}

\author{
Eficacia de la terapia con sildenafil para el tratamiento de la hipertensión pulmonar en perros: \\ revisión sistemática
}

\author{
AC Silva ${ }^{a}$, G Oberlender ${ }^{b}$, MM Mantovani $^{\mathrm{a}}$, RAL Muzzi ${ }^{2}$, LJ Pereira ${ }^{\mathrm{b}}$, MG Zangeronimo ${ }^{\mathrm{b}}$ \\ a Division of Small Animal Medicine, Section of Veterinary Cardiology, Department of Veterinary Medicine, \\ Federal University of Lavras, Lavras, Minas Gerais, Brazil.

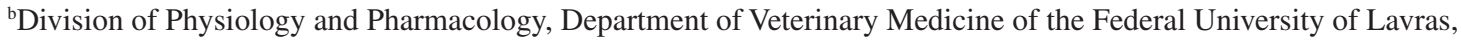 \\ Lavras, Minas Gerais, Brazil.
}

\begin{abstract}
RESUMEN
El objetivo de esta revisión sistemática fue evaluar la eficacia del sildenafil en el tratamiento de la hipertensión pulmonar (HP) en perros y, cuando posible, proponer recomendaciones a favor o en contra de su uso. Se realizaron búsquedas electrónicas en seis bases de datos internacionales. El criterio de inclusión fue estudios clínicos in vivo que evaluaron la eficacia del sildenafil en el tratamiento de la HP de origen natural. El sistema de clasificación se diseñó para considerar aspectos como la forma de distribución y enmascaramiento de los tratamientos experimentales, número de animales empleados, asociación con otros medicamentos, métodos de diagnóstico para HP, evaluaciones de la respuesta clínica al tratamiento y efectos adversos. Un total de cinco artículos fueron obtenidos. En general, la condición clínica y la calidad de vida de los animales mejoraron después de la terapia con el sildenafil, y la incidencia de efectos adversos fue poco común. Los hallazgos ecocardiográficos proporcionaron evidencia de cambios en la presión arterial pulmonar que podrían asociarse con alteraciones en la actividad física y tiempo de supervivencia. Aún así, la calidad metodológica de los estudios fue baja, ya que sólo un estudio fue un ensayo clínico al azar, placebo-controlado y doble ciego. Con poca evidencia, este estudio permitió establecer que el sildenafil es una terapia importante que puede tener un papel terapéutico positivo en el tratamiento de HP canina. Se recomienda realizar estudios prospectivos al azar, ciegos y controlados con un mayor número de animales para evaluar la actividad física y los efectos adversos del sildenafil y otras drogas, así como la eficacia de este medicamento en perros.
\end{abstract}

Palabras clave: caninos, enfermedad pulmonary, terapia, sildenafil.

\section{SUMMARY}

This systematic review aimed to assess the efficacy of sildenafil in the treatment of pulmonary hypertension ( $\mathrm{PH}$ ) in dogs and, when possible, to propose recommendations for or against its use. Electronic searches were carried out using six international databases. The inclusion criterion was in vivo clinical trials that assessed the efficacy of sildenafil in the treatment of naturally occurring $\mathrm{PH}$. The scoring system was designed to take into account aspects such as the form of distribution and masking of experimental treatments, the number of animals, association with other drugs, diagnostic methods for PH, evaluations of the clinical response to treatment and adverse effects. A total of five papers were found. In general, the clinical condition and quality of life of the animals improved after sildenafil therapy, and the occurrence of adverse effects was uncommon. Echocardiographic findings provided evidence for changes in pulmonary arterial pressure which could be associated with alterations in physical activity and survival time. Still, the methodological quality of the studies was low, only one of them was a randomised, placebo-controlled and double-blind clinical trial. Furthermore, with modest evidence, this study allowed the recommendation that sildenafil is an important therapy which can play a positive therapeutic role in the treatment of canine PH. Additionally, prospective, randomised, blinded and controlled studies with a larger number of animals assessing physical activity and the adverse effects of sildenafil and other drugs in association are recommended to evaluate the efficacy of this drug in dogs.

Key words: canine, pulmonary disease, therapy, sildenafil.

\section{INTRODUCTION}

Pulmonary hypertension $(\mathrm{PH})$ is a complex syndrome characterised by elevated pressure (systolic/diastolic) in the pulmonary arterial circulation (in dogs and humans = more than $25.0 \mathrm{mmHg}$ at rest), resulting in an increase in vascular resistance in the lung, which leads to increased

Accepted: 24.10.2013.

*ralmuzzi@dmv.ufla.br. right ventricular cardiac overload (Johnson et al 1999). Regarding its aetiology, PH may be idiopathic (primary), or in most cases, secondary to both respiratory and cardiac alterations. In dogs with left heart failure, for example, PH is often an associated condition (Stepien 2009). There are several clinical signs associated with the occurrence of PH, such as cough, tachypnea, syncope, respiratory distress, right-side heart failure and others (Bach et al 2006, Kellihan and Stepien 2010). Even with recent advances in symptomatic treatments, there is no cure currently available for this disease (Humbert et al 2004). 
However, in recent years, several drugs have been developed which can help to improve the quality of life and increase survival time in human and animal patients with PH (Humbert et al 2004, Kellihan and Stepien 2010).

Sildenafil citrate is a drug that acts by selectively inhibiting phosphodiesterase type 5 (PDE5), and is a potent pulmonary vasodilator (Toyoshima et al 2007). PDE5 is the predominant form of phosphodiesterase found in the lung; it metabolises cyclic guanosine monophosphate (cGMP), which is related to nitric oxide degradation. Therefore, by selectively inhibiting PDE5, sildenafil can lead to the accumulation of intracellular cGMP and therefore increase nitric oxide-mediated vasodilatation (Galiè et al 2005).

In dogs with PH-induced acute pulmonary embolism sildenafil has been shown to act by improving clinical signs, mainly through its action on the pulmonary circulation, and it also has shown good results in isolated perfused lung models (in vitro) (Dias-Junior et al 2005, Souza-Silva et al 2005). However, in animals that develop a clinical form of PH, other conditions may be associated with this disease, and response to treatment may be different. In addition, in dogs, pulmonary thromboembolism is a rare cause of PH (Jorens et al 2009), while left heart dysfunction is one of the main associated aetiologies (Kellihan and Stepien 2010). On the other hand, heartworm disease, although less common, can be one of the aetiologies associated with PH in dogs (Johnson et al 1999, Pyle et al 2004).

In humans, several studies have demonstrated the beneficial effects of sildenafil in the treatment of $\mathrm{PH}$ (Michelakis et al 2003, Galiè et al 2005, Humpl et al 2005, Gan et al 2007). Also, in animals such as piglets (Rondelet et al 2004) and mice (Takimoto et al 2005), important pulmonary and cardiac effects of sildenafil treatment have been demonstrated. On the other hand, few studies in dogs have been conducted to evaluate the efficacy of sildenafil in the treatment of PH (Bach et al 2006, Kellum and Stepien 2007, Brown et al 2010), even though this drug is consistently used in the routine clinical care of small animals.

Therefore, the aim of the present study was to systematically review the efficacy of sildenafil treatment on $\mathrm{PH}$ in dogs as described in the literature and, when possible, to suggest recommendations for or against its use.

\section{MATERIAL AND METHODS}

\section{SEARCH STRATEGIES}

Electronic searches were carried out in September 2012 using the MEDLINE PUBMED database with the following keywords: [dog OR dogs OR canine] and [pulmonary hypertension] and [sildenafil OR Viagra] and [treatment] (see http://www.ncbi.nlm.nih.gov/pubmed/). To confirm the findings and obtain supplementary studies, a similar strategy was employed with the ISI WEB OF SCIENCE database (see http://apps.webofknowled- ge.com/), the SCIENCEDIRECT database (see http:// www.sciencedirect.com/), the SCOPUS database (see http://www.scopus.com/), the SCIELO database (see http://www.scielo.org/) and the COCHRANE database (see http://cochrane.bvsalud.org/). The same sequence of keywords was used as search criteria, in all databases.

In addition to the search performed in six databases, another search was carried out through the auxiliary evaluation of all references in the articles selected for this review in an attempt to recover any article that had not been previously obtained (Faggion et al 2011). For the presentation and discussion of data, additional papers were used, including review articles, when appropriate.

\section{SELECTION OF PAPERS}

For this review, only papers related to in vivo clinical trials that assessed the efficacy of the drug sildenafil in the treatment of pulmonary hypertension in dogs were selected. Review articles, letters, editorial comments and meeting abstracts were excluded. Evaluations of this medication in studies that investigated experimentally-induced PH and/or pulmonary embolism were not used. Similarly, in vitro studies were not utilised in this review. There were no restrictions based on the number of animals (Pereira $e t$ al 2011) or the selection of case reports, when its main objective was to evaluate the efficacy of sildenafil treatment for PH in dogs. In addition, there was also no restriction regarding to the etiology of $\mathrm{PH}$ since this disease may originate from various factors (multifactorial disease). The search was limited to scientific papers published in peerreviewed veterinary or medical journals indexed in the aforementioned databases, without limitations regarding the year and date of publication. No restrictions were made with regard to the language in which the paper was published, provided that the abstract was available in English.

\section{DATA EXTRACTION}

Searches using the selected databases and keywords were carried out separately by the researchers in accordance with the established criteria. Afterwards, the definition of papers for inclusion was performed during a consensus meeting among the researchers (Silva AC, Oberlender $\mathrm{G}$ and Mantovani MM), taking into consideration the statistical design, quality of the methodology, quality of subject enrolment, type of intervention and outcome evaluations. In the case of divergent opinions on the papers, all criteria were reviewed and discussed to produce a single result. The data were displayed in tables and compared based on the pre-established criteria.

\section{ASSESSMENT OF THE QUALITY OF PAPERS}

After the selection of articles, analyses of the studies were conducted and scores were assigned through spe- 
cific criteria to obtain the degree of methodological evidence and final results. Adapted from other systematic reviews (Nuttall et al 2007, Negre et al 2009, Pereira et al 2011), various data were classified as adequate (score: 3 ), unclear/partly adequate (score: 2 ) or inadequate (score: 1$)$. Some parameters were classified only as adequate (score: 2 ) or inadequate (score: 1 ). The details of the scores of the evaluated parameters are shown below:

Type of study. If the study was controlled by a form of distribution and masking of the experimental treatment, if the researchers/observers and patients/owners had no knowledge of the treatment method and if the study also included blinded evaluations.

The scores were presented as the following distribution: randomised, blinded, controlled studies, including a control group with another active drug or placebo and/ or prospective studies (score: 3 ); controlled trials but lacking randomisation and/or blinding or retrospective studies (score: 2) and open studies, uncontrolled tests/case reports/descriptive studies (score: 1 ).

Number of animals. Scores for the number of samples were 1 (less than four animals/group), 2 (5-19 animals/ group) and 3 (20 or more animals/group).

Drugs used. Treatment using only sildenafil (score: 2); treatment using a combination of sildenafil with one or more drugs (score: 1).

Pulmonary hypertension diagnostic method. Pulmonary artery catheterisation and echocardiographic examination, chest radiography, history and physical examination (score: 2); echocardiographic examination, chest radiograph, history and physical examination (score: 1).

Evaluation of clinical treatment response. Echocardiographic examination, physical examination, monitoring of physical activity and questionnaire completed by the owner (score: 3); echocardiographic examination, physical examination, and questionnaire completed by the owner (score: 2); echocardiographic examination in the absence of one or more previously described exams (score: 1).

Adverse effects of the drug. Papers that reported the presence or absence of adverse effects following the administration of sildenafil (score: 2); studies that did not evaluate adverse effects (score: 1 ).

The maximal total possible score was 15 points.

\section{RESULTS}

Table 1 depicts the results of the search with all combinations of keywords. The search strategy initially identified a total of 77 articles in the PubMed database (MEDLINE), but only five were selected for this review.
The ISI WEB OF SCIENCE, SCIENCEDIRECT, SCOPUS, SCIELO and COCHRANE databases returned 48, 407, 37, 0 and 1 articles, respectively; no additional study was obtained for this review. The total number of articles found was 570; however, the number of selected articles was greater than the number of articles used for this review due to the fact that some studies were found in several searches using different combinations of keywords. From the total number of studies evaluated, 30 were excluded due to the fact that they were literature reviews, 13 were letters and 10 were meeting abstracts. Papers by Lee et al (2010) and Seibert et al (2010), despite having been obtained in the search, were excluded because the main objective in these studies was not to evaluate the efficacy of sildenafil in the treatment of PH.

At the end of the selection phase and after determining which articles were adequate according to the criteria previously established by the researchers, five studies were obtained that assessed the efficacy of sildenafil in the treatment of PH. Regarding these selected articles, one was a prospective, double-blind, randomised, crossover study (Brown et al 2010), one was a prospective study (Nakamura et al 2011), two studies were retrospective (Bach et al 2006, Kellum and Stepien 2007) and one was a case report (Toyoshima et al 2007).

Briefly, the experimental methodology and the main results obtained in the selected articles evaluating sildenafil in the treatment of $\mathrm{PH}$ in dogs are described in table 2. Table 3 depicts the scores of these studies based on the proposed evaluation methodology.

In all studies, a total of 55 animals were evaluated, including 25 males $(45.45 \% ; 21$ neutered and 4 intact) and 30 females $(54.55 \% ; 25$ spayed and 5 intact). In three studies, the number of females was greater than males. The general population consisted of two mixed-breed dogs and 53 purebred dogs.

The age of the animals ranged from 7 months to 15 years and 10 months and the weight ranged from 2.3 to $39.1 \mathrm{~kg}$. Only one study had more than 20 animals (Kellum and Stepien 2007); three studies used between 5 and 19 animals of which two used 13 (Bach et al 2006, Brown et al 2010) and one 5 animals (Nakamura et al 2011). One study used only 1 animal (Toyoshima et al 2007). Among the selected articles, sildenafil doses administered to dogs ranged from 0.5 to $5.6 \mathrm{mg} / \mathrm{kg}$ and the dosing intervals were every 8,12 and 24 hours.

Regarding the etiology of $\mathrm{PH}$, all evaluated studies described respiratory and heart diseases as its mainly cause, however, one study reported secondary erythrocytosis due to Eisenmenger's syndrome as a cause of PH. Systolic blood pressure (systemic) (SBP) was measured in three of five selected papers (Bach et al 2006, Kellum and Stepien 2007, Brown et al 2010). In all studies, the SBP values were higher before the start of treatment with sildenafil, given that after the period of therapy SBP was numerically lower, but statistically there was no difference 


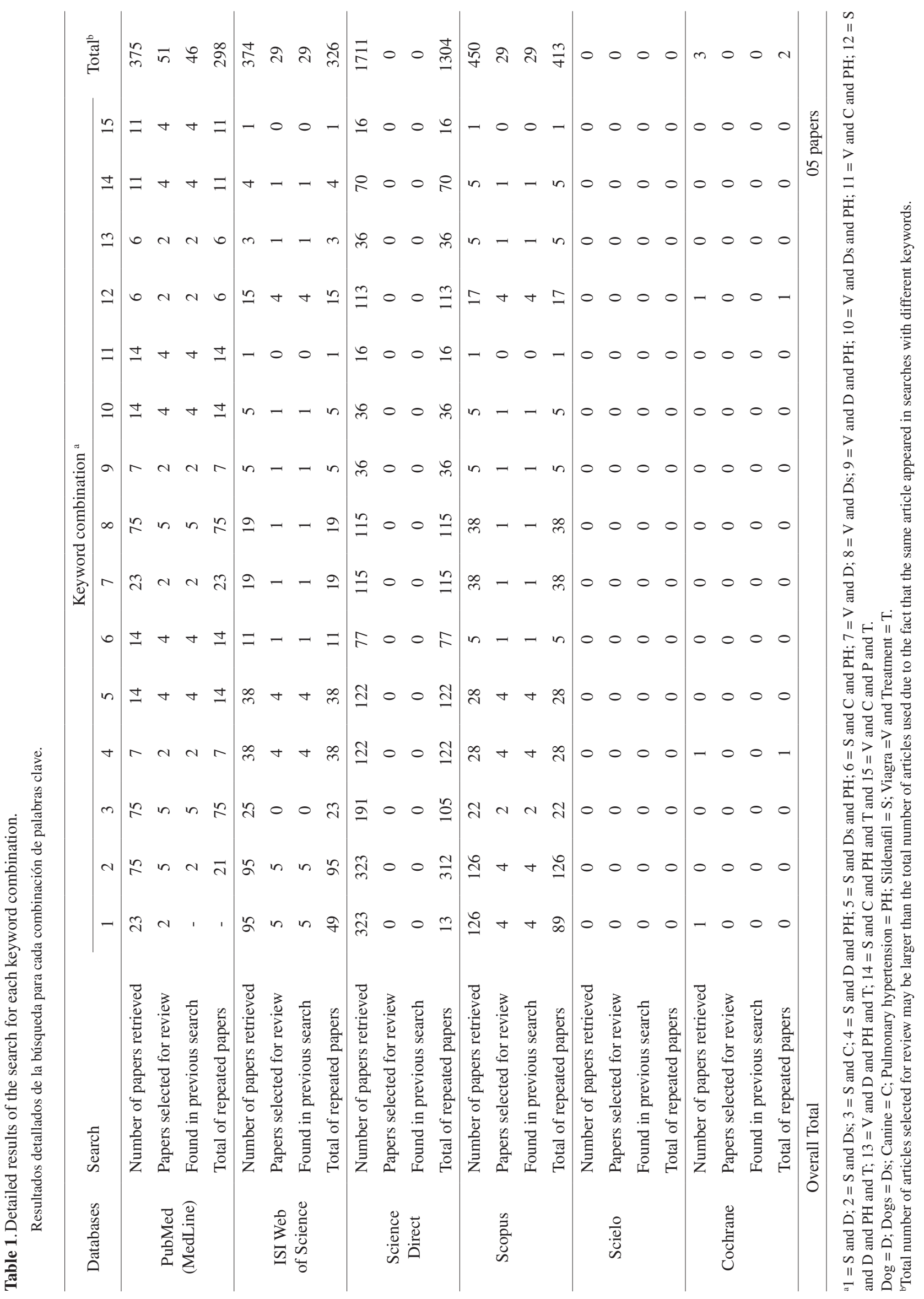


Table 2. Summary of data from trials reporting the treatment of pulmonary hypertension in dogs.

Resumen de los datos de los ensayos que informaron el tratamiento de la hipertensión pulmonar en perros.

\begin{tabular}{|c|c|c|c|c|c|}
\hline & Bach et al. (2006) & $\begin{array}{l}\text { Kellum and Stepien } \\
\text { (2007) }\end{array}$ & $\begin{array}{c}\text { Toyoshima et al } \\
\text { (2007) }\end{array}$ & $\begin{array}{l}\text { Brown et al } \\
\quad(2010)\end{array}$ & $\begin{array}{l}\text { Nakamura } \\
\text { et al (2011) }\end{array}$ \\
\hline Animals a & $13(0 / 13)$ & $22(0 / 22)$ & $1(0 / 1)$ & $13(7 / 6)$ & $5(0 / 5)$ \\
\hline Gender $^{b}$ & $5 / 8$ & $6 / 16$ & $1 / 0$ & $11 / 2$ & $2 / 3$ \\
\hline Breed & $\begin{array}{l}3 \text { Shihtzus; } 2 \text { Chi- } \\
\text { huahuas; } 2 \text { Golden } \\
\text { Retrievers; } 1 \text { Cairn } \\
\text { Terrier; } 1 \text { Labrador } \\
\text { Retriever; } 1 \text { Maltese; } \\
1 \text { Pug; } 1 \text { Pekinese } \\
\text { and 1 Fox Terrier }\end{array}$ & $\begin{array}{c}3 \text { West Highland White Ter- } \\
\text { riers; } 3 \text { Miniature Poodles; } 2 \\
\text { Maltese; } 2 \text { Yorkshire Terriers; } \\
2 \text { Scottish Terriers; } 1 \text { Austra- } \\
\text { lian Cattle Dog; } 1 \text { Japanese } \\
\text { Chin; } 1 \text { Rat Terrier; } 1 \text { Nor- } \\
\text { wich Terrier; } 1 \text { Cavalier King } \\
\text { Charles Spaniel; } 1 \text { Welsh } \\
\text { Terrier; } 1 \text { Brittany Spaniel; } 1 \\
\text { American Water Spaniel; } 1 \\
\text { Springer Spaniel and } 1 \text { mix- } \\
\text { breed }\end{array}$ & 1 Papillon & $\begin{array}{c}\text { Chihuahuas; } 2 \\
\text { Cocker Spaniels; } 2 \\
\text { Dachshunds; } \\
\text { 1 Dalmatian; 1 Jack } \\
\text { Russell Terrier; } 1 \\
\text { Pomeranian; } \\
\text { 1 Shihtzus; } \\
1 \text { Lhasa Apso } \\
\text { and } 1 \text { mixbreed }\end{array}$ & $\begin{array}{c}2 \text { Miniature } \\
\text { Dachshunds; } \\
1 \text { Ameri- } \\
\text { can Cocker } \\
\text { Spaniel; } 1 \\
\text { Pomeranian } \\
\text { and } 1 \text { Shetland } \\
\text { Sheepdog }\end{array}$ \\
\hline $\begin{array}{l}\text { Sildenafil } \\
\text { dose }\end{array}$ & $\begin{array}{l}\text { Median dose of } 1.9 \\
\mathrm{mg} / \mathrm{kg} \text { (range, } 0.5 \text { to } \\
2.7 \mathrm{mg} / \mathrm{kg} \text { ) }\end{array}$ & $\begin{array}{l}\text { Median dose of } 3.13 \mathrm{mg} / \mathrm{kg} / \\
\text { day (range, } 2.08 \text { to } 5.56 \mathrm{mg} / \\
\mathrm{kg} \text { ) }\end{array}$ & $1.0 \mathrm{mg} / \mathrm{kg}$ & $1.0 \mathrm{mg} / \mathrm{kg}$ & $0.5 \mathrm{mg} / \mathrm{kg}$ \\
\hline $\begin{array}{l}\text { Duration of } \\
\text { administra- } \\
\text { tion }\end{array}$ & $\begin{array}{l}\text { Until the animal } \\
\text { death being } 693 \text { days } \\
\text { the maximum sur- } \\
\text { vival period }\end{array}$ & $\begin{array}{l}\text { Until the animal death being } \\
734 \text { days the maximum sur- } \\
\text { vival period }\end{array}$ & $\begin{array}{l}\text { Four years } \\
\text { (48 months) }\end{array}$ & $\begin{array}{l}\text { Total period of } \\
\text { eight weeks }\end{array}$ & $\begin{array}{l}\text { Three months } \\
\text { (90 days) }\end{array}$ \\
\hline $\begin{array}{l}\text { Dosing } \\
\text { interval }\end{array}$ & Eight to 24 hours & Once a day & $\begin{array}{l}\text { Twice a day until } \\
\text { three years of treat- } \\
\text { ment, and after } \\
\text { three times a day }\end{array}$ & $\begin{array}{l}\text { Every eight hours } \\
\text { (three times a day) }\end{array}$ & Twice a day \\
\hline $\operatorname{Drug}^{c}$ & $\begin{array}{l}\text { Sildenafil, furose- } \\
\text { mide, angiotensin- } \\
\text { converting enzyme } \\
\text { inhibitor, amlodip- } \\
\text { ine, diltiazem, the- } \\
\text { ophylline, phenobar- } \\
\text { bital and antibiotics }\end{array}$ & $\begin{array}{l}\text { Sildenafil, furosemide, enala- } \\
\text { pril, terbutaline, amlodipine } \\
\text { and doxycycline }\end{array}$ & Just sildenafil & $\begin{array}{c}\text { Sildenafil, furose- } \\
\text { mide, } \\
\text { enalapril, pimoben- } \\
\text { dan, } \\
\text { digoxin, spironolac- } \\
\text { tone, aldactazide, } \\
\text { deracoxib } \\
\text { and lysodren }\end{array}$ & Just sildenafil \\
\hline $\begin{array}{l}\text { Period of } \\
\text { evaluation }\end{array}$ & $\begin{array}{l}\text { Until the animal } \\
\text { death being } 693 \text { days } \\
\text { the maximum sur- } \\
\text { vival period }\end{array}$ & $\begin{array}{l}\text { Until the animal death being } \\
734 \text { days the maximum survi- } \\
\text { val period }\end{array}$ & $\begin{array}{c}1.460 \text { days (4th } \\
\text { week; } 3 \text { th month; } \\
\text { 3th year and 4th } \\
\text { year after therapy) }\end{array}$ & $\begin{array}{l}56 \text { days }(0,4 \text { th and } \\
\text { 8th week after initiat- } \\
\text { ing therapy }\end{array}$ & $\begin{array}{l}90 \text { days (ba- } \\
\text { seline, } 1 \text { th } \\
\text { month and 3th } \\
\text { month) }\end{array}$ \\
\hline $\begin{array}{l}\text { Etiology of } \\
\text { pulmonary } \\
\text { hyperten- } \\
\text { sion }\end{array}$ & $\begin{array}{c}\text { Chronic pulmonary } \\
\text { disease (5 animals); } \\
\text { chronic valvular } \\
\text { heart disease (1); } \\
\text { PDA (1); pulmonary } \\
\text { thromboembolism } \\
\text { (1) and idiopathic - } \\
\text { primary (5) }\end{array}$ & $\begin{array}{c}\text { PDA (1 animal); respiratory } \\
\text { disease (11) and heart disease } \\
\text { ( } 9 \text { animals })\end{array}$ & $\begin{array}{l}\text { Respiratory and } \\
\text { heart disease }\end{array}$ & $\begin{array}{c}\text { Chronic } \\
\text { valvular heart disease }\end{array}$ & $\begin{array}{l}\text { Secondary } \\
\text { erythrocytosis } \\
\text { due to Eisen- } \\
\text { menger's syn- } \\
\text { drome }\end{array}$ \\
\hline $\begin{array}{l}\text { Diagnostic } \\
\text { method } \\
\text { for pulmo- } \\
\text { nary hyper- } \\
\text { tension }\end{array}$ & $\begin{array}{l}\text { Pulmonary artery } \\
\text { catheterization or } \\
\text { Doppler echocar- } \\
\text { diography; being } \\
\text { defined as a PAP } \geq \\
25 \mathrm{mmHg} \text { at rest }\end{array}$ & $\begin{array}{l}\text { Conventional echocardiog- } \\
\text { raphy and Doppler echocar- } \\
\text { diography; being defined as } \\
\text { PTRFV } \geq 2,8 \mathrm{~m} / \mathrm{s} \text { or PTRFG } \\
\geq 31,4 \mathrm{mmHg} \text { or PPIFV } \geq 2,2 \\
\mathrm{~m} / \mathrm{s} \text { or PPIFG } \geq 19 \mathrm{mmHg}\end{array}$ & $\begin{array}{l}\text { Coventional echo- } \\
\text { cardiography and } \\
\text { Doppler echocar- } \\
\text { diography; being } \\
\text { defined as PAP > } \\
\quad 20 \mathrm{mmHg}\end{array}$ & $\begin{array}{l}\text { Echocardiography } \\
\text { and Doppler echocar- } \\
\text { diography; being that } \\
\text { dogs were included if } \\
\text { their PGs was at least } \\
\quad 60 \mathrm{mmHg}\end{array}$ & $\begin{array}{l}\text { Echocardiog- } \\
\text { raphy and } \\
\text { Doppler echo- } \\
\text { cardiography }\end{array}$ \\
\hline
\end{tabular}




\begin{tabular}{|c|c|c|c|c|c|}
\hline $\begin{array}{l}\text { Criteria for } \\
\text { inclusion }\end{array}$ & $\begin{array}{c}\text { Dogs with } \\
\text { PAP } \geq 25 \mathrm{mmHg} \text { at } \\
\text { rest }\end{array}$ & $\begin{array}{l}\text { Dogs who received sildenafil } \\
\text { to treat echocardiographically } \\
\text { identified PH and who had at } \\
\text { least one follow-up echocar- } \\
\text { diographic examination after } \\
\text { at least } 7 \text { days of sildenafil } \\
\text { therapy }\end{array}$ & Not applicable & $\begin{array}{c}\text { PGs at least } 60 \\
\text { mmHg and } \\
\text { no evidence of ste- } \\
\text { nosis } \\
\text { in the pulmonic valve }\end{array}$ & $\begin{array}{l}\text { Dogs with } \\
\text { secondary } \\
\text { erythrocy- } \\
\text { tosis due to } \\
\text { Eisenmenger's } \\
\text { syndrome, } \\
\text { intra- or extra- } \\
\text { cardiac com- } \\
\text { munication } \\
\text { with a right-to- } \\
\text { left shunt }\end{array}$ \\
\hline $\begin{array}{l}\text { Criteria for } \\
\text { exclusion }\end{array}$ & Unclear & $\begin{array}{l}\text { Dogs who received antihyper- } \\
\text { tensive medication other than } \\
\text { angiotensin converting } \\
\text { enzyme inhibitors were ex- } \\
\text { cluded from the } \\
\text { SBP analysis. Dogs who re- } \\
\text { ceived angiotensin-converting } \\
\text { enzyme } \\
\text { inhibitors were excluded if } \\
\text { the dose was changed be- } \\
\text { tween examination points }\end{array}$ & Not applicable & $\begin{array}{l}\text { Concurrent radio- } \\
\text { graphic evidence of } \\
\text { pulmonary edema } \\
\text { consistent with left- } \\
\text { sided congestive heart } \\
\text { failure, or they had } \\
\text { systemic hyperten- } \\
\text { sion/hypotension } \\
\text { (>180mmHg or } \\
<100 \mathrm{mmHg} \text { as mea- } \\
\text { sured by Doppler) or } \\
\text { any nonrelated severe } \\
\text { comorbid condition. } \\
\text { Also if angiotensin } \\
\text { converting enzyme } \\
\text { inhibitors or phospho- } \\
\text { diesterase inhibitors } \\
\text { had been added to the } \\
\text { treatment regimens } \\
\text { within the prior } 4 \\
\text { weeks the dogs were } \\
\text { excluded }\end{array}$ & Unclear \\
\hline $\begin{array}{c}\text { Type of } \\
\text { assay }\end{array}$ & Retrospective study & Retrospective study & Case report & $\begin{array}{l}\text { Prospective short- } \\
\text { term, randomized, } \\
\text { placebo controlled, } \\
\text { double-blind and } \\
\text { crossover study }\end{array}$ & $\begin{array}{l}\text { Prospective, } \\
\text { single arm, } \\
\text { and open-label } \\
\text { study }\end{array}$ \\
\hline $\begin{array}{l}\text { Main re- } \\
\text { sults after } \\
\text { the treat- } \\
\text { ment with } \\
\text { sildenafil }\end{array}$ & $\begin{array}{l}\text { Decrease in SBP but } \\
\text { not statistically dif- } \\
\text { ferent; PAP decrease; } \\
\text { cought, syncope and } \\
\text { respiratory effort } \\
\text { were decreased; the } \\
\text { owners felt that their } \\
\text { dogs were clinically } \\
\text { improved and me- } \\
\text { dian survival time } \\
\text { was } 175 \text { days (range, } \\
28-693 \text { days) }\end{array}$ & $\begin{array}{c}\text { Decrease in SBP but not } \\
\text { statistically different; no sig- } \\
\text { nificant improvement in PAP; } \\
\text { increase in the } \\
\text { PA AT:ET ratio; clinical im- } \\
\text { provement in activity, exer- } \\
\text { cise ability, ease of breathing, } \\
\text { demeanor, cought; decreased } \\
\text { ascites in affected animals } \\
\text { and cessation or reduced } \\
\text { frequency of syncopal or } \\
\text { collapse episodes and median } \\
\text { survival time was } 247 \text { days } \\
\text { (range, 8-698 days) }\end{array}$ & $\begin{array}{l}\text { Pulmonary artery } \\
\text { PGs decrease; exer- } \\
\text { cise capacity, cya- } \\
\text { nosis, dyspnea and } \\
\text { cardiac murmur } \\
\text { were improved; } \\
\text { improved of poly- } \\
\text { cytemia by increas- } \\
\text { ing the medication } \\
\text { frequency and } \\
\text { positive effects } \\
\text { after four years of } \\
\text { treatment }\end{array}$ & $\begin{array}{c}\text { Decrease in SBP } \\
\text { but not statistically } \\
\text { different; tricuspid } \\
\text { valve PGs decrease; } \\
\text { no changes in heart } \\
\text { rate; frequency and } \\
\text { exercise tolerance in- } \\
\text { creased and improved } \\
\text { quality life }\end{array}$ & $\begin{array}{l}\text { A significant } \\
\text { improvement } \\
\text { in modified } \\
\text { functional } \\
\text { class; reduc- } \\
\text { tion of packed } \\
\text { cell volume } \\
\text { and increase } \\
\text { in the } \\
\text { PA AT:ET } \\
\text { ratio }\end{array}$ \\
\hline $\begin{array}{c}\text { Adverse } \\
\text { effect }\end{array}$ & $\begin{array}{l}\text { Gastrointestinal and } \\
\text { cutaneous flushing in } \\
\text { the inguinal region }\end{array}$ & $\begin{array}{c}\text { Lethargy, somnolence, } \\
\text { clear nasal discharge, and } \\
\text { erect ears }\end{array}$ & Absent & Absent & Absent \\
\hline
\end{tabular}

${ }^{a}$ Animals - Total number of animals and average number of animals per group (placebo/treated).

${ }^{\mathrm{b}}$ Gender (Male/Female).

'Drug (Just sildenafil or association with other drugs). 
Table 3. Scores achieved by each article according to the criteria evaluated.

Calificaciones obtenidas por cada artículo conforme los criterios evaluados.

\begin{tabular}{|c|c|c|c|c|c|c|c|}
\hline \multirow[b]{2}{*}{ Author } & \multicolumn{7}{|c|}{ Evaluation criteria } \\
\hline & $\begin{array}{c}\text { Mean } \\
\text { number of } \\
\text { animals per } \\
\text { group }^{\mathrm{a}}\end{array}$ & $\begin{array}{l}\text { Type } \\
\text { of } \\
\text { assay }^{b}\end{array}$ & $\begin{array}{l}\text { Drug } \\
\text { used }^{\mathrm{c}}\end{array}$ & $\begin{array}{l}\text { Diagnostic } \\
\text { method for } \\
\text { pulmonary } \\
\text { hypertension }\end{array}$ & $\begin{array}{l}\text { Evaluation } \\
\text { of clinical } \\
\text { response to } \\
\text { treatment }\end{array}$ & $\begin{array}{c}\text { Adverse } \\
\text { effect }^{\mathrm{f}}\end{array}$ & Total \\
\hline Brown et al (2010) & 2 & 3 & 1 & 1 & 3 & 2 & 12 \\
\hline Bach et al (2006) & 2 & 2 & 1 & 2 & 2 & 2 & 11 \\
\hline Kellum and Stepien (2007) & 3 & 2 & 1 & 1 & 1 & 2 & 10 \\
\hline Nakamura et al (2011) & 2 & 2 & 2 & 1 & 1 & 2 & 10 \\
\hline Toyoshima et al (2007) & 1 & 1 & 2 & 1 & 1 & 2 & 8 \\
\hline
\end{tabular}

${ }^{a}$ Scores for the sample number were 1 (less than four animals/group), 2 (4-19 animals/group) and 3 (20 or more animals/group).

${ }^{b}$ Randomized, double-blinded and controlled study; control group with active drug or placebo and prospective studies (score 3), controlled trial but with lack of randomization and/or blinding and retrospective study (score 2) and open study, tests uncontrolled, case reports and descriptive study (score 1). cTherapy that used only sildenafil (score 2) and treatment that used sildenafil in association with one or more drugs (score 1).

${ }^{d}$ Pulmonary artery catheterization and echocardiographic evaluation, toracic radiograph, historic and physical exam (score 2) and echocardiographic evaluation, toracic radiograph, historic and physical exam (score 1).

eEchocardiographic examination, physical examination, monitoring of physical activity and questionnaire with the owner (score: 3). Echocardiographic examination, physical examination, and questionnaire with the owner (score: 2). Echocardiographic examination in the absence of one or more exams described previously (score: 1 ).

${ }^{\mathrm{f}}$ The papers that reported the presence or absence of adverse effects on the administration of sildenafil (score: 2).

before and after treatment. In addition to measures of systolic pressure, Bach et al (2006) showed increased diastolic blood pressure values after treatment with sildenafil, although this increase was not statistically significant.

The administration of other drugs in addition of sildenafil occurred in three studies, of which the angiotensin converting enzyme (ACE) inhibitors furosemide and spironolactone were the most commonly used. In the study conducted by Bach et al (2006), 77\% of the animals were treated with other drugs. Kellum and Stepien (2007) demonstrated the use of other medications in $32 \%$ of animals.

In all the selected papers, the diagnosis of $\mathrm{PH}$ was performed by echocardiography in various forms. Kellum and Stepien (2007) used Doppler echocardiography and two-dimensional echocardiography (2-D) to determine the peak tricuspid regurgitation flow velocity (PTRFV) and peak pulmonic insufficiency flow velocity (PPIFV). In this study, the presence of a PTRFV greater than or equal to $2.8 \mathrm{~m} / \mathrm{s}$ and a peak tricuspid regurgitation gradient flow (PTRFG) greater than or equal to 31.4 $\mathrm{mmHg}$ or a PPIFV greater than or equal to $2.2 \mathrm{~m} / \mathrm{s}$ or a peak pulmonic insufficiency flow gradient (PPIFV) greater than or equal to $19.0 \mathrm{mmHg}$ was considered to be abnormally high and indicative of $\mathrm{PH}$.

Bach et al (2006) measured systolic pulmonary arterial pressure (PAPs) by pulmonary artery catheterisation or Doppler echocardiography, with values greater than or equal to $25.0 \mathrm{mmHg}$ at rest indicative of disease. On the other hand, Brown et al (2010), by means of 2-D echocardiography, M-mode and Doppler, assessed the systolic pres- sure gradient (PGs) in the tricuspid valve. Values greater than or equal to $60 \mathrm{mmHg}$ were taken as indicative of $\mathrm{PH}$.

Regarding pulmonary arterial pressure, Brown et al (2010) observed a significant reduction $(\mathrm{P}=0.018)$ in $\mathrm{PGs}$ in the tricuspid valve (through Bernoulli's equation) after treatment with sildenafil compared to baseline. Bach et al (2006) and Toyoshima et al (2007) also showed positive results with sildenafil administration. In the former study, there was a significant reduction of PAPs $(P=0.036)$. Six out of eight animals showed a mean decrease of 16.5 $\mathrm{mmHg}(16.7 \%)$. In the latter study, the PGs in the pulmonary artery decreased after three months of therapy.

Kellum and Stepien (2007) did not obtain significant improvement in pulmonary artery pressure (evaluated by tricuspid regurgitation and pulmonary insufficiency) after treatment with sildenafil. The peak tricuspid regurgitation flow gradient numerically decreased after the administration of sildenafil (before, $58 \mathrm{mmHg}$; range, 35-169, and after, $55 \mathrm{mmHg}$; range, 30-179), but did not differ statistically; a decrease in PGs is not associated with a significant decrease in this variable.

Nakamura et al (2011) did not evaluate pulmonary arterial pressure. Pulmonary or tricuspid regurgitation were also not determined due to the fact that it was not present. In this study, the values between the acceleration time of pulmonary artery (AT) and ejection time (ET) (PA AT:ET) ratio, assessed by pulsed Doppler echocardiography, were chosen for the evaluation of pulmonary haemodynamics. In this study, the PA AT:ET ratio increased after one month of therapy with sildenafil $(\mathrm{P}=0.063)$. A 
similar increase in PA AT:ET was observed in the study by Kellum and Stepien (2007).

The evaluation of the clinical response to treatment with sildenafil was performed in several ways, including conventional echocardiography, Doppler echocardiography, physical examination, radiography and laboratory tests, questionnaires completed by the owners as well as through monitoring and an evaluation of physical activity in the animals.

Physical examination, conventional echocardiography and Doppler echocardiography were performed for monitoring and evaluating the treatment response in all five selected studies. Only the study by Brown et al (2010) included monitoring the physical activity of animals during therapy and also assessed quality of life by means of a questionnaire administered to the owners before and after treatment of the animals with sildenafil. Chest radiography after treatment was performed in two studies; differences in vertebral heart size and pulmonary infiltrates were not observed (Kellum and Stepien 2007, Toyoshima et al 2007).

Interviews and information regarding the clinical status were assessed and analysed in three studies (Bach et al 2006, Kellum and Stepien 2007, Brown et al 2010). One modified functional class was used to evaluate the animals in the study by Nakamura et al (2011). Laboratory tests after treatment with sildenafil were assessed in the study by Brown et al (2010); no differences were observed after treatment. Kellum and Stepien (2007) also used ECG findings as a method to assess the therapeutic response.

In terms of physical examinations, there were no changes in heart rate before and after treatment in the study by Brown et al (2010). Kellum and Stepien (2007) also found no clinically significant changes in murmur and respiratory signs in animals after therapy. At the clinical evaluation of the animals after treatment with sildenafil, among many analysed variables, an increase in physical activity and exercise tolerance, improvements in breathing patterns, reduction of syncope, improved behaviour, decrease of ascites in the affected animals, improvement or cessation of coughing, cyanosis, dyspnoea and episodes of collapse were obtained (Bach et al 2006, Kellum and Stepien 2007, Toyoshima et al 2007, Brown et al 2010).

The physical activity of animals and quality of life were evaluated in the study by Brown et al (2010) by means of a device placed on the collar around the neck of each dog during the study and by a specific questionnaire, respectively. In this work, increased physical activity and quality of life were observed during the treatment of dogs with sildenafil when compared to placebo treatment. The other studies observed improvements in physical activity and quality of life only by means of a questionnaire and clinical examination.

The median survival time was evaluated in two studies (Bach et al 2006, Kellum and Stepien 2007). The survival time was 8 to 698 days. Although Kellum and Stepien (2007) obtained a higher median survival time, the variation between studies was similar. The occurrence of respiratory failure and progressive respiratory distress were the main causes of death or euthanasia in some animals, respectively.

Only two studies reported the occurrence of adverse effects in animals that received sildenafil, and no dogs discontinued therapy because of these effects (Bach et al 2006, Kellum and Stepien 2007). In the former study, adverse gastrointestinal effects were observed in one dog. Two owners reported inguinal redness in their dogs, and one dog did not experience this side effect with a lower dosage of sildenafil. In the latter study, about $18 \%$ of the animals (four dogs) presented sleepiness, lethargy, clear nasal discharge and erect ears.

\section{DISCUSSION}

The present systematic review employed explicit methods to carry out a detailed bibliographic study and allowed a clearer visualisation of the results. Six international databases of considerable scientific importance were used in order to ensure the broad scope of the search. It should be pointed out that PubMed (MedLine), ISI Web of Science and Scopus were the only databases that yielded all the papers selected for the review due to the fact that the content of these databases encompasses articles in both the fields of human and veterinary biomedicine. Despite the fact that the Science Direct database returned the largest number of articles by different keyword combinations, no articles from this database were selected for the present review.

The criteria used for the construction of this review were defined with the aim of assessing the efficacy of the administration of sildenafil on PH in dogs as well as the methodological quality of the selected studies. Some limitations of this study should be addressed. Some of the articles published on this subject may not have been retrieved due to the fact that the title did not contain the descriptors employed or the indexed keywords. However, the authors made considerable effort to avoid missing any article in the composition of this review. It should also be mentioned that the criteria regarding the assessment of methodological quality were defined based on the experience of the authors and are therefore not definitive.

The exclusion of papers that used sildenafil in the treatment of experimentally-induced $\mathrm{PH}$ and/or pulmonary embolism in dogs was done as the purpose of this review was the evaluation of the drug in clinical trials (naturally occurring $\mathrm{PH}$ ). In addition, thromboembolism in dogs is a rare cause of $\mathrm{PH}$ as observed in several studies (Johnson et al 1999, Pyle et al 2004, Bach et al 2006, Kellum and Stepien 2007, Serres et al 2007). Left heart dysfunction is one of the main associated aetiologies (Kellihan and Stepien 2010).

Most dogs with PH were small breeds and middleaged to elderly, which has also been reported by other 
studies (Pyle et al 2004, Serres et al 2007). This occurrence is explained by the greater predisposition of older dogs and small breeds to degenerative mitral valve disease and chronic lung diseases, both of which may cause PH. However, Toyoshima et al (2007) and Nakamura et al (2011) evaluated puppies or young adults, with PH secondary to congenital heart diseases. With regard to gender, the occurrence of a higher number of females is not reported as a sexual predisposition to the disease.

The doses of sildenafil as well as the dosing intervals were quite variable ( 0.5 to $5.6 \mathrm{mg} / \mathrm{kg}$, once or twice a day, respectively) in the evaluated studies. However, regardless of this variation, positive results were observed in all treated animals. Despite the choice of dose and frequency of administration depending on the severity of $\mathrm{PH}$ and the clinical condition of the animal, sildenafil has the disadvantage of a short duration of action (half-life of approximately 4 hours) (Toyoshima et al 2007). This fact can be adjusted by increasing the frequency of administration of the drug, as observed in most studies.

The decrease in SBP observed in three studies (Bach et al 2006, Kellum and Stepien 2007, Brown et al 2010) was not expected since the PDE5 is highly localised in the corpus cavernosum and lung; in addition, its activity is increased in PH (Corbin et al 2005). It is known that sildenafil has major effects on vascular resistance in the lung; however, the selectivity of PDE5 inhibitors in dogs is not known, and sildenafil may also have an effect on systemic vascular resistance and blood pressure (Bach et al 2006).

According to Trojnarska and Plaskota (2009), a decrease in pulmonary pressure in response to drugs, including sildenafil, may decrease systemic pressure. According to Nakamura et al (2011), this effect may lead to an increased right-to-left shunt, followed by a decrease in blood saturation and further aggravation the clinical status of the animal. It should be noted that the measurement of SBP has some variability when performed at different times and, primarily, by different individuals. Therefore, SBP monitoring should be conducted carefully before, during and after treatment with sildenafil. Thus, in case of complications and side effects, sildenafil therapy must be reassessed.

In the study by Bach et al (2006), the diagnosis of PH was directly made by pulmonary artery catheterisation and the assessment of PAPs and indirectly through Doppler echocardiography. The use of catheterisation is the gold standard for a definitive diagnosis of PH (Toyoshima et al 2007). Nevertheless, this technique is often accompanied by great risk because is invasive and may not be performed in most patients with severe disease; however, when performed it provides numerous haemodynamic parameters which help in the aetiological classification of the disease (Kellihan and Stepien 2010).

In veterinary medicine, the standard method for the non-invasive detection of $\mathrm{PH}$ is echocardiography (Pyle et al 2004, Zabka et al 2006) in its various available modalities, including 2-D imaging, Doppler flow examinations and tissue Doppler examinations, which provide additional information to the diagnosis of disease (Serres et al 2007). Two-dimensional and echodopplercardiographic examinations provide the diagnosis in most clinical veterinary patients and are the methods of choice to diagnose naturally occurring PH (Johnson et al 1999, Schober and Baade 2006, Kellihan and Stepien 2010). In all selected studies, the diagnostic method of PH was made by echocardiography in its various modalities. By means of Doppler echocardiography, evaluations of the peak flow velocity of tricuspid valve regurgitation and pulmonary artery regurgitation and an estimation of pressure gradients can be used as diagnostic methods for $\mathrm{PH}$ (Kellihan and Stepien 2010). In addition to these measurements, the assessment of the systolic time interval of the right ventricle by AT, ET and the AT:ET ratio and the pre-ejection period (PEP) have been used to support the diagnosis of PH in dogs (Uehara 1993, Johnson et al 1999, Baade and Schober 2006).

Kellum and Stepien (2007) and Nakamura et al (2011) obtained values of the PA AT:ET ratio consistent with PH. According to Schober and Baade (2006), values of AT:ET less than or equal to 0.31 seconds and an AT value less than or equal to 0.058 seconds are predictive of $\mathrm{PH}$ and are useful to diagnose the disease in animals that do not present insufficient valve flows. In the study by Nakamura et al (2011), the diagnosis of PH was performed by means of the AT: ET ratio, probably since none of the five animals presented pulmonary or tricuspid regurgitation during the study.

According to Kellum and Stepien (2007), the PA AT:ET ratio obtained by Doppler echocardiography presents enormous variability when used in dogs with $\mathrm{PH}$ of various aetiologies. This fact explains the results found in their study because, although the median ratio was 0.3 seconds and the AT was 0.05 seconds, which are within the cut-off values, $43 \%$ of the AT:ET ratios and $38 \%$ of the AT values were higher than the recommended values. Despite this, the study used other methods to confirm PH in the dogs.

Monitoring the clinical response to treatment with sildenafil may be performed using various tools. Re-evaluation by Doppler echocardiographic and radiographic examinations, questionnaires to assess the quality of life and exercise tolerance tests are often performed in animals (as demonstrated in the five selected articles) as well as in humans (Sastry et al 2004, Jackson et al 2010). Brown et al (2010) used an accelerometer and showed that dogs increased their level of physical activity during treatment with sildenafil. On the other hand, in the second phase of the crossover study, it was shown that physical activity in the animals decreased. This suggests that severe $\mathrm{PH}$ is progressive and demonstrates that exercise tolerance is likely to deteriorate over time regardless of therapy. 
The occurrence of PH has been associated with poor prognosis in dogs, with a survival time ranging from 14 to 35 days after diagnosis (Johnson et al 1999). Bach et al (2006) and Kellum and Stepien (2007) observed median survival time greater than 150 days after beginning treatment with sildenafil. According to Ghio et al (2001), human patients with right ventricular dysfunction have a worse prognosis compared to other conditions, due to the establishment of severe PH. In dogs, the association of $\mathrm{PH}$ with chronic respiratory diseases also determines a worse prognosis through the establishment of severe $\mathrm{PH}$ (Pyle et al 2004). Therefore, it has been observed that the survival time is brief due to complications associated with the clinical status of the animals.

The use of different combinations of drugs in the treatment of $\mathrm{PH}$ was demonstrated in three of the selected studies. According to Kellihan and Stepien (2010), PH generates several disorders and abnormalities in various organ systems and functional mechanisms, not only in the lung; therefore, its treatment is based on the correction of all present conditions. As in most cases, heart disease is associated with the occurrence of PH. In this case, the combined use of different drugs is required for treatment (Pyle et al 2004). Also, the use of combinations of drugs with different mechanisms of action in order to increase the clinical benefit has been studied, mainly in human medicine. In cases where a combination of different medications is used, it is difficult to associate the occurrence of improvements and side effects with sildenafil (Kellum and Stepien 2007). Therefore, in all evaluated studies, the large number and variation of medications used in the dogs limited some other important considerations.

The use of sildenafil in the majority of evaluated cases was well-tolerated and associated with a significant improvement in clinical signs in dogs with PH. Although the studies by Bach et al (2006) and Kellum and Stepien (2007) reported the occurrence of adverse effects in animals, these could not be linked exclusively to the use of sildenafil because the dogs received additional medications in these studies. Thus, no conclusions can be made because the adverse effects may have been due to the other medications administered.

In humans, adverse effects reported due to therapy with sildenafil include headache, dyspnoea, visual disturbances, nasal congestion, priapism, myalgia, gastric alterations, back pain and redness (Karatzas et al 2005). In dogs, many of these signs can be difficult to recognise. Therefore, although the combination of drugs promoted an improvement in clinical signs and disease, a detailed investigation into the adverse effects of sildenafil should be done through the administration of only this drug to animals.

There is a limited number of published studies (five) that evaluated this drug in the treatment of naturally occurring PH in dogs. There was only one randomised, placebo controlled and double-blind clinical trial that evalua- ted the efficacy of this drug. These facts show that the decision on the therapeutic use of sildenafil in the treatment of PH in dogs was based on only a few scientific publications in veterinary medicine, or based mainly on studies in human medicine, experimentally-induced $\mathrm{PH}$ or in vitro studies in dogs, and often on personal experience, rather than evidence-based medicine. Possible solutions associated with several existing limitations include:

- An evaluation of a greater number of animals, although recruitment of adequate numbers may entail multicentre studies;

- Long-term studies, mainly evaluating the effectiveness of treatment and possible side effects of chronic administration;

- Prospective, randomised, blinded, controlled and multicentre studies are needed, thus increasing the level of methodological evidence to further evaluate the effectiveness of sildenafil for canine $\mathrm{PH}$;

- More specific studies with respect to side effects, mainly through the administration, if possible, of only sildenafil without other drugs;

- Additionally, further studies are needed to determine if sildenafil has an added benefit compared to other drugs for PH in dogs, mainly by assessing survival time.

It is concluded that this systematic review allows the recommendation, with modest evidence, that sildenafil is an important therapy that can play a positive therapeutic role in the treatment of canine PH. Furthermore, according to the papers used in this study, the use of sildenafil in the majority of evaluated cases was well-tolerated and associated to significant improvement in clinical signs and physical activity in dogs with PH. In the recommendation view point, the ideal dose and the dosing intervals of sildenafil can range from 0.5 to $5.6 \mathrm{mg} / \mathrm{kg}$ and 8,12 and 24 hours, respectively. The overall quality and quantity of studies reporting the efficacy of sildenafil for $\mathrm{PH}$ is poor.

\section{ACKNOWLEDGEMENTS}

This work was partially supported by FAPEMIG (the Research Support Foundation of the State of Minas Gerais), CNPq (the National Council for Scientific and Technological Development), CAPES (Coordination of Improvement of Higher Education Personnel), the Veterinary Medicine and Animal Science Graduate Programme and the Graduate Directory of the Federal University of Lavras, Brazil.

\section{REFERENCES}

Bach JF, EA Rozanski, J MacGregor, JM Betkowski, JE Rush. 2006. Retrospective evaluation of sildenafil citrate as a therapy for pulmonary hypertension in dogs. J Vet Intern Med 20, 1132-1135.

Brown AJ, E Davison, MM Sleeper. 2010. Clinical efficacy of sildenafil in treatment of pulmonary hypertension in dogs. $J$ Vet Intern Med 24, 850-854. 
Corbin JD, A Beasley, MA Blount, SH Francis. 2005. High lung PDE5: a strong basis for treating pulmonary hypertension with PDE5 inhibitors. Biochem Biophys Res Commun 334, 930-938.

Dias-Junior CA, DC Souza-Costa, T Zerbini, JBT Rocha, RF Gerlach, JE Tanus-Santos. 2005. Effect of sildenafil on pulmonary embolism-induced oxidative stress and pulmonary hypertension. Anesth Analg 101, 115-120.

Faggion Jr. CM, S Listl, NN Giannakopoulos. 2011. The methodological quality of systematic reviews of animal studies in dentistry. Vet $J$ 192, 140-147.

Galiè N, HA Ghofrani, A Torbicki, RJ Barst, LJ Rubin, D Badesch, T Fleming, T Parpia, G Burgess, A Branzi, F Grimminger, A Kurzyna, G Simonneau. 2005. Sildenafil citrate therapy for pulmonary arterial hypertension. $N$ Engl $J$ Med 353, 2148-2157.

Gan CT, S Holverda S, JT Marcus, WJ Paulus, KM Marques, JGF Bronzwaer, JW Twisk, A Boonstra, PE Postmus, A Vonk-Noordegraaf. 2007. Right ventricular diastolic dysfunction and the acute effects of sildenafil in pulmonary hypertension patients. Chest 132, 11-17.

Ghio S, A Gavazzi, C Campana, C Inserra, C Klersy, R Sebastiani, E Arbustini, F Recusani, L Tavazzi. 2001. Independent and additive prognostic value of right ventricular systolic function and pulmonary artery pressure in patients with chronic heart failure. J Am Coll Cardiol 37, 183-188.

Humbert M, O Sitbon, G Simonneau. 2004. Treatment of pulmonary arterial hypertension. $N$ Engl J Med 351, 14251436.

Humpl T, JT Reyes, H Holtby, D Stephens, I Adatia. 2005. Beneficial effect of oral sildenafil therapy on childhood pulmonary arterial hypertension: twelve-month clinical trial of a single-drug, open-label, pilot study. Circulation 111, 3274-3280.

Johnson L, J Boon, EC Orton. 1999. Clinical characteristics of 53 dogs with Doppler-derived evidence of pulmonary hypertension: 1992-1996. J Vet Intern Med 13, 440-447.

Jorens PG, E Van Marck, A Snoeckx, PM Parizel. 2009. Nonthrombotic pulmonary embolism. Eur Respir J 34, 452-474.

Karatza AA, A Bush, AG Magee. 2005. Safety and efficacy of sildenafil therapy in children with pulmonary hypertension. Intern J Cardiol 100, 267-273.

Kellihan HB, RL Stepien. 2010. Pulmonary hypertension in dogs: diagnosis and therapy. Vet Clin North Am Small Anim Pract 40, 623-641.

Kellum HB, RL Stepien. 2007. Sildenafil Citrate therapy in 22 dogs with pulmonary hypertension. J Vet Intern Med 21, 1258-1264.

Lee JS, R Choi, SH Han, C Hyun. 2010. Double outlet right ventricle in a maltese dog. $J$ Vet Clin 27, 735-739.

Michelakis ED, W Tymchak, M Noga, L Webster, XC Wu, D Lien, SH Wang, D Modry, SL Archer. 2003. Long-term treatment with oral sildenafil is safe and improves functional capacity and hemodynamics in patients with pulmonary arterial hypertension. Circulation 108, 2066-2069.

Nakamura K, M Yamasaki, H Ohta, N Sasaki, M Murakami,
WR Bandula Kumara, M Takiguchi. 2011. Effects of sildenafil citrate on five dogs with Eisenmenger's syndrome. J Small Anim Pract 52, 595-598.

Negre A, E Bensignor, J Guillot. 2009. Evidence-based veterinary dermatology: a systematic review of interventions for Malassezia dermatitis in dogs. Vet Dermatol 1, 1-12.

Nuttall T, LK Cole. 2007. Evidence-based veterinary dermatology: a systematic review of interventions for treatment of Pseudomonas otitis in dogs. Vet Dermatol 18, 69-77.

Pereira UP, DGS Oliveira, LR Mesquita, GM Costa, LJ Pereira. 2011. Efficacy of Staphylococcus aureus vaccines for bovine mastitis: a systematic review. Vet Microbiol 148, 117-124.

Pyle RL, J Abbott, H MacLean. 2004. Pulmonary hypertension and cardiovascular sequelae in 54 dogs. Intern J Appl Res Vet Med 2, 99-109.

Rondelet B, F Kerbaul, R Van Beneden, S Motte, P Fesler, I Hubloue, M Remmelink, S Brimioulle, I Salmon, JM Ketelslegers, R Naeije. 2004. Signaling molecules in overcirculation-induced pulmonary hypertension in piglets: effects of sildenafil therapy. Circulation 110, 2220-2225.

Schober KE, H Baade. 2006. Doppler Echocardiographic prediction of pulmonary hypertension in West Highland White Terriers with chronic pulmonary disease. $J$ Vet Intern Med 20, 912-920.

Seibert RL, HW Maisenbacher, R Prosěk, DB Adin, WG Arsenault, AH Estrada. 2010. Successful closure of left-to-right patent ductus arteriosus in three dogs with concurrent pulmonary hypertension. $J$ Vet Cardiol 12, 67-73.

Serres F, V Chetboul, V Gouni, R Tissier, CC Sampedrano, JL Pouchelon. 2007. Diagnostic value of echo-Doppler and tissue Doppler imaging in dogs with pulmonary arterial hypertension. J Vet Intern Med 21, 1280-1289.

Souza-Silva AR, CA Dias-Junior, JA Uzuelli, H Moreno Jr., PR Evora, JE Tanus-Santos. 2005. Hemodynamic effects of combined sildenafil and 1-arginine during acute pulmonary embolism-induced pulmonary hypertension. Eur $J$ Pharmacol 524, 126-131.

Stepien RL. 2009. Pulmonary arterial hypertension secondary to chronic left-sided cardiac dysfunction in dogs. J Small Anim Pract 50, 34-43.

Takimoto E, HC Champion, M Li, D Belardi, S Ren, ER Rodriguez, D Bedja, KL Gabrielson, Y Wang, DA Kass. 2005. Chronic inhibition of cyclic GMP phosphodiesterase 5A prevents and reverses cardiac hypertrophy. Nat Med 11, 214-222.

Toyoshima Y, I Kanemoto, S Arai, H Toyoshima. 2007. A case of long-term Sildenafil therapy in a young dog with pulmonary hypertension. J Vet Med Sci 69, 1073-1075.

Trojnarska O, K Plaskota. 2009. Therapeutic methods used in patients with Eisenmenger syndrome. Cardiol J 16, 500-506.

Uehara Y. 1993. An attempt to estimate the pulmonary artery pressure in dogs by means of pulsed Doppler echocardiography. $J$ Vet Med Sci 55, 307-312.

Zabka TS, FE Campbell, DW Wilson. 2006. Pulmonary arteriopathy and idiopathic pulmonary arterial hypertension in six dogs. Vet Pathol 43, 510-522. 
